УДК 342.7

\author{
Ю. B. Гаруст \\ доктор юридичних наук, доцент, \\ завідувач кафедри адміністративного, господарського права та фінансово-економічної безпеки \\ Сулського державного університету \\ В. С. Степановський \\ магістр \\ Навчально-наукового інституту права \\ Сулського державного університету
}

\title{
АДМІНІСТРАТИВНО-ПРАВОВИЙ СТАТУС СЛУЖБИ БЕЗПЕКИ УКРАЇНИ ЯК СУБ'СКТА ЗАБЕЗПЕЧЕННЯ ФІНАНСОВО-ЕКОНОМІЧНОЇ БЕЗПЕКИ ДЕРЖАВИ
}

Стабільний фінансово-економічний розвиток держави натепер є запорукою ї̈ соціально-економічного розвитку, у тому числі подолання багатьох негативних явищ у суспільстві та економіці, належного виконання взятих на себе перед міжнародними інституціями боргових зобов'язань. Разом із тим забезпечення такого розвитку вимагає ефективної діяльності багатьох суб’єктів владних повноважень, правоохоронних органів тощо. Одним із таких правоохоронних органів $\epsilon$ Служба безпеки України (далі - СБУ). Зважаючи на призначення зазначеного органу, низка наукових праць уже була присвячена статусу Служби безпеки України. Зокрема, Р. Баранецький, М. Віхляєв, О. Грідін, М. Грек, А. Кумейко, О. Нападистий, О. Полковніченко, С. Пономарьов, А. Савченко, I. Фурман звертали увагу на зазначене питання. Разом із тим в умовах реформування сектору безпеки України, зростання рівня загроз фінансово-економічним інтересам держави це питання не втрачає своєї актуальності.

Відповідно, метою статті є дослідження адміністративно-правового статусу СБУ як суб'єкта забезпечення фінансово-економічної безпеки держави.

Викладення основного матеріалу доцільно розпочати з того, що натепер відсутнє єдине трактування поняття «фінансово-економічна безпека держави». На доктринальному рівні з'ясуванню сутності вказаної дефініції присвячено низку праць як правників, так і економістів. На думку Я. Жаліло, економічна безпека країни - багатофакторна категорія, що характеризує спроможність національної економіки до розширеного самовідтворення 3 метою збалансованого задоволення потреб населення, протистояння дестабілізуючому впливу внутрішніх і зовнішніх чинників, забезпечення конкурентоспроможності національної економіки [1, с. 31]. Що стосується поняття "фінансова безпека», то варто зазначити, що Н. Кравчук визначає іï як: захищеність фінансових інтересів суб'єктів господарювання на всіх рівнях фінансових відносин, забезпеченість домашніх господарств, підприємств, організацій і установ, регіонів, галузей, секторів економіки, держави фінансовими ресурсами, достатніми для задоволення їхніх потреб і виконання наявних зобов'язань [2, с. 122].

При цьому слід погодитись 3 О. Іващенко та В. Гельманом, що забезпечення фінансово-економічної безпеки держави потребує вирішення широкого кола проблем, що стосуються формування критеріїв та принципів забезпечення фінансово-економічної безпеки, визначення пріоритетних національних інтересів у фінансовій сфері, здійснення постійного відстеження факторів, які викликають загрози фінансово-економічній безпеці країни, а також вживання заходів щодо їх попередження та подолання [3]. Аналіз нормативно-правової бази дає змогу зробити висновок, що відстеження загроз фінансово-економічній безпеці держави, вжиття заходів щодо їх виявлення, припинення є завданням правоохоронних органів України. Так, Закон України «Про державний захист працівників суду і правоохоронних органів» від 23 грудня 1992 року [4] до правоохоронних органів відносить низку органів, у тому числі органи безпеки. А згідно зі ст. 17 Конституції України [5] та ст. 1 Закону «Про Службу безпеки України» [6] передбачено, що державним правоохоронним органом спеціального призначення, на який покладено забезпечення державної безпеки України, $е$ СБУ. Виходячи з чого очевидно, що СБУ уповноважена забезпечувати державну безпеку України, що є одним із напрямів реалізації правоохоронної функції держави, але слід погодитись також з науковцями, що специфіка правоохоронних органів проявляється у тому, що вони водночас $є$ і органами державного управління, оскільки на них поряд з правоохоронними завданнями покладаються й управлінські [7, с. 9]. Наявність у правоохоронних органів управлінських функцій дає нам підстави говорити про їхній адміністративно-правовий статус і СБУ не є винятком.

С. Пономарьов вважає, що структура адміністративно-правового статусу СБУ включає функціонально-цільовий, структурно-організаційний, компетенційний блоки, піднаглядність 
і відповідальність правоохоронного органу, гарантії його діяльності [8, с. 123]. Така структура адміністративно-правового статусу зумовлена особливими завданнями та повноваженнями СБУ, спеціальним порядком її утворення, реорганізації, ліквідації, підконтрольності, підзвітності, здійснення нею керівництва, формування кадрів, призначення та звільнення працівників [9, с. 23-24]. Разом із тим вважаємо, що піднаглядність СБУ не слід окремо виділяти, позаяк це складник організаційно-структурного елемента.

Дискусійним є і віднесення гарантій до структури адміністративно-правового статусу СБУ, оскільки включення їх до структури правового статусу спостерігається переважно в роботах, присвячених індивідуальним суб'єктам, тоді як для публічних суб’єктів (крім органів місцевого самоврядування) законодавство їх загалом не передбачає [10, с. 241].

На думку О. Грідіна, адміністративно-правовий статус СБУ - це встановлений правовий режим виконання повноважень спеціального органу, завдань, повноважень та форм діяльності у сфері забезпечення державної безпеки України [11, с. 302]. При цьому очевидно, що науковець суттєво обмежує зміст адміністративно-правового статусу СБУ, залишаючи поза увагою структуру спецслужби, відповідальність та інші важливі елементи.

Виходячи із вищевказаних підходів до розуміння адміністративно-правового статусу СБУ, можна зробити висновок, що він являє собою визначене нормами адміністративного права становище СБУ серед інших правоохоронних органів як суб'єктів захисту фінансово-економічної безпеки держави, що знаходить своє закріплення в меті, завданнях, функціях, організаційній структурі, компетенції, відповідальності спецслужби.

Так, слід погодитись з Т. Момотенко, що визначальним фактором діяльності правоохоронних органів є їх завдання та функції: метою діяльності $€$ виконання законодавчо закріплених за ними завдань, а нерозривно з метою та завданнями правоохоронних органів потрібно розглядати і функції як відносно самостійні та якісні однорідні складники діяльності, які характеризуються цільовою спрямованістю і є провідним напрямом діяльності органу, із чим варто погодитися [12, с. 128].

Виходячи з положень статті 1 Закону України «Про Службу безпеки України», ми можемо зробити висновок, що метою діяльності спецслужби є забезпечення державної безпеки України, одним зі складників якої є фінансово-економічна безпека держави. Про нерозривний зв'язок мети і завдань СБУ свідчить зміст статті 2 вищевказаного Закону, де до завдань спецслужби віднесено попередження, виявлення, припинення та розкриття корупції та організованої злочинної діяльності у сфері управління і економіки та інших протиправних дій, які безпосередньо створюють загрозу життєво важливим інтересам України [6]. Тобто закріплена стаття фактично свідчить про наявність у СБУ повноважень у сфері захисту фінансово-економічної безпеки держави. Водночас функції спецслужби законодавець не визначає, що, на нашу думку, є суттєвим недоліком у розумінні адміністративно-правового статусу СБУ.

Говорячи про організаційно-структурний елемент адміністративно-правового статусу СБУ, слід наголосити, що він включає в себе такі елементи, як: порядок утворення та ліквідації, підпорядкованість, організаційна структура. Своєю чергою основними елементами організаційної будови є: керівництво органу (керівник та його заступники); апарат та територіальні органи; підприємства, установи, організації, що належать до сфери його управління; консультативні, дорадчі та інші допоміжні органи [13, с. 85]. У Законі України «Про Службу безпеки України» чітко передбачено, що систему СБУ становлять Центральне управління СБУ, підпорядковані йому регіональні органи, органи військової контррозвідки, військові формування, а також навчальні, науково-дослідні та інші заклади СБУ. При цьому організаційна структура СБУ визначається Президентом України. Крім того, глава держави також призначає та звільняє з посади голову СБУ, а також його заступників за відповідним поданням останнього [6].

Слід зауважити, що в структурі Центрального управління СБУ як суб'єкта забезпечення фінансово-економічної безпеки держави функціонує Головне управління контррозвідувального захисту інтересів держави у сфері економічної безпеки, яке здійснює контррозвідувальну діяльність 3 метою виявлення наявних або потенційних загроз економічній, а відповідно, і фінансовій системам та їх оперативного усунення. Однак такі висновки можна зробити лише з назви вказаного управління, позаяк саме Положення про Головне управління контррозвідувального захисту інтересів держави у сфері економічної безпеки має гриф «Для службового користування».

Значимість завдань, покладених на СБУ як правоохоронного органу спеціального призначення, зумовлює посилений механізм їі підзвітності та підконтрольності. Відповідно до статей 31 та 32 Закону України «Про Службу безпеки України» постійний контроль за діяльністю СБУ, дотриманням нею законодавства здійснюється Верховною Радою України, а тому голова СБУ щорічно подає до парламенту звіт про діяльність спецслужби. Крім того, контроль за діяльністю СБУ здійснюється Президентом України та уповноваженими ним державними органами, главі держави також щорічно подається звіт про результати діяльності СБУ [6].

Переходячи до компетенції як одного з елементів адміністративно-правового статусу СБУ, слід 
підкреслити, що їі зміст переважно визначають як сукупність встановлених в офіційній формі прав та обов'язків, тобто повноважень будь-якого органу чи посадової особи, які визначають можливості цього органу або посадової особи приймати обов'язкові до виконання рішення, організовувати та контролювати їх виконання, вживати в необхідних випадках заходів відповідальності [14, с. 90]. На законодавчому рівні права та обов'язки СБУ регламентовані статтями 24, 25 Закону України «Про Службу безпеки України», зокрема: 1) здійснювати інформаційно-аналітичну роботу в інтересах ефективного проведення органами державної влади та управління України внутрішньої і зовнішньої діяльності, вирішення питань, пов'язаних з національною безпекою України; 2) здійснювати заходи з охорони державних інтересів у сфері зовнішньоекономічної діяльності; 3) виявляти, припиняти, розслідувати та розкривати кримінальні правопорушення, розслідування яких віднесено законодавством до компетенції СБУ, зокрема зміст ст. 216 КПК України свідчить про те, що спецслужба може здійснювати досудове розслідування за ст. 209 ККУ «Легалізація (відмивання) доходів, одержаних злочинним шляхом» та ст. 2091 ККУ «Умисне порушення вимог законодавства про запобігання та протидію легалізації (відмиванню) доходів, одержаних злочинним шляхом, або фінансування тероризму»; 4) здійснювати контррозвідувальні заходи з метою попередження, виявлення, припинення і розкриття будь-яких форм розвідувально-підривної діяльності проти України; 5) здійснювати контррозвідувальний захист економічних інтересів держави; 6) брати участь у розробці і здійсненні згідно із Законом України «Про державну таємницю» заходів щодо забезпечення охорони державної таємниці; 7) здійснювати профілактику правопорушень у сфері державної безпеки; 8) надавати допомогу органам поліції, іншим правоохоронним органам у боротьбі із вчиненням кримінальних правопорушень; 9) проводити наукові дослідження і дослідно-конструкторські роботи, впроваджувати їх результати в практичну діяльність; 10) виконувати за дорученням Президента України інші завдання, спрямовані на забезпечення внутрішньої та зовнішньої безпеки держави [6].

Таким, що визначає статус СБУ як спеціального правоохоронного органу держави, є право на здійснення контррозвідувальної діяльності. На думку О. Степанченко, контррозвідувальна діяльність СБУ з виявлення загроз економіці $€$ діяльністю, здійснюваною спеціально підготовленими співробітниками оперативних підрозділів СБУ за допомогою підбору джерел, формування каналів одержання інформації, алгоритмізованої обробки з використанням спеціальних аналітичних прийомів сукупності даних, отриманих у ре- зультаті здійснення різних заходів і наступного вироблення експертних оцінок у формі спеціалізованих документів [15]. Своєю чергою М. Грек звертає увагу, що завданнями СБУ як уповноваженого органу державної влади у сфері контррозвідувальної діяльності є: 1) добування, аналітичне оброблення та використання інформації, що містить ознаки або факти розвідувальної, терористичної та іншої діяльності спеціальних служб іноземних держав, а також організацій, окремих груп та осіб на шкоду державній безпеці України; 2) протидія розвідувальній, терористичній та іншій діяльності спеціальних служб іноземних держав, а також організацій, окремих груп та осіб на шкоду державній безпеці України; 3) розроблення і реалізація заходів щодо запобігання, усунення та нейтралізації загроз інтересам держави, суспільства та правам громадян [16. с. 245]. Зазначене знайшло своє закріплення і в Законі Україні «Про контррозвідувальну діяльність» від 26 грудня 2002 року.

Виходячи з викладеного, можна зробити висновок, що СБУ для здійснення своїх завдань як суб'єкта забезпечення фінансово-економічної діяльності має інформаційно-аналітичні, оперативно-розшукові повноваження, повноваження щодо досудового розслідування, контррозвідки, забезпечення збереження державної таємниці, взаємодії з іншими правоохоронними органами та суб'єктами тощо.

Останнім елементом адміністративно-правового статусу СБУ, який визначає її особливий статус, є юридична відповідальність. Д. Лук'янець визначає юридичну відповідальність як: регламентовану правовими нормами реакцію з боку уповноважених суб'єктів на діяння фізичних або юридичних осіб (колективних суб'єктів), що можуть мати вираз у недотриманні встановлених законом заборон, невиконанні встановлених законом обов'язків, порушенні цивільно-правових зобов'язань, нанесенні шкоди або завданні збитків і виражена у застосуванні до осіб, що вчинили такі діяння, засобів впливу, які тягнуть за собою позбавлення особистого, майнового або організаційного характеру [17]. При цьому ст. 35 Закону України «Про Службу безпеки України» закріплює, що співробітники СБУ, які виконують свої обов'язки відповідно до наданих законодавством повноважень і в рамках закону, не несуть відповідальності за завдані майнові збитки, оскільки вони компенсуються за рахунок державного бюджету СБУ. Натепер засади такої відповідальності СБУ регламентовано також Законом України «Про порядок відшкодування шкоди, завданої громадянинові незаконними діями органів, що здійснюють оперативно-розшукову діяльність, органів досудового розслідування, прокуратури і суду» від 1 грудня 1994 року.

Втім, зазначеними положеннями юридична відповідальність СБУ не обмежується, позаяк 
рішення, дії чи бездіяльність співробітників спецслужби можуть бути оскаржені до суду в адміністративному порядку.

Таким чином, СБУ є одним із суб'єктів забезпечення фінансово-економічної безпеки держави, адміністративно-правовий статус СБУ являє собою визначене нормами адміністративного права становище СБУ серед інших правоохоронних органів як суб'єктів захисту фінансово-економічної безпеки держави, що знаходить своє закріплення в меті, завданнях, функціях, організаційній структурі, компетенції та юридичній відповідальності спецслужби.

\section{Jimepamypa}

1. Жаліло Я. Стратегія забезпечення економічної безпеки України. Стратегія національної безпеки України в контексті досвіду світової спільноти. Київ : Сатсанга. 2001. С. 141-152.

2. Кравчук Н. Фінансова безпека держави: реальність і доцільність в умовах глобалізації. Вісник Тернопільської акаделії народного господарства. 2000. Вип. 9. С. 121-126.

3. Іващенко O.В., Гельман В.М. Фінансово-економічна безпека держави. Збірник наукових праць Таврійського державного агротехнологічного університету (економічні науки). 2013. № 2 (1). С. 121-131.

4. Конституція України : Закон України від 28.06.1996 р. Відомості Верховної Ради України. 1996. № 30. Ст. 141.

5. Про державний захист працівників суду і правоохоронних органів : Закон України від 23.12.1993 р. Відомості Верховної Ради України. 1994. № 11. Ст. 50.

6. Про Службу безпеки України : Закон України від 25.03.1992 р. Відомості Верховної Ради України. 1992. № 27. Ст. 382 .

7. Організація судових та правоохоронних органів : підручник / за ред. I.Є. Марочкіна. Харків : Право. 2013. $448 \mathrm{c}$.

8. Пономарьов С.П. Адміністративно-правовий статус органів Служби безпеки України. Право і безпека. 2012. № 3. С. 121-125.

9. Баранецький Р.Ф. Щодо статусу Служби безпеки України як органу державної влади. Юридична наука. 2015. № 2. C. $22-27$.

10. Хамходера О.П. Адміністративно-правовий статус державних інспекцій: проблемні питання структури. Право і суспільство. 2014. № 5-2. С. 238-244.

11. Грідін О.В. Адміністративно-правовий статус Служби безпеки України. Держава і право. 2010. Вип. 48. С. 298-303.

12. Момотенко Т.Д. Правоохоронні органи: поняття і сутність. Право і безпека. 2014. № 4 (55). C. 127-131.

13. Лавренова O.I. Організаційно-структурні аспекти адміністративно-правового статусу державної служби як центрального органу виконавчої влади. $\epsilon_{8}$ ропейські перспективи. 2014. № 6. С. 81-86.

14. Лазор О. Місцеве управління: поняття, терміни, визначення : навчальний посібник. Київ : Дакор. 2006. $352 \mathrm{c}$.

15. Степанченко 0.0. Понятійно-категорійний апарат контррозвідувального захисту Службою безпеки України економіки держави. Вісник Луганського державного університету внутрішніх справ ім. Е.О. Дідоренка. 2013. № 1. С. 307-312.
16. Грек М. Завдання Служби безпеки України як правоохоронного органу. Публічне право. 2012. № 3 (7). C. $240-247$.

17. Лук'янець Д.М. Типологія юридичної відповідальності. Юридична Україна. № 3. 2004. С. 4-10.

\section{Анотація}

Гаруст Ю. В., Степановський В. С. Адміністративно-правовий статус Служби безпеки України як суб'єкта забезпечення фінансово-економічної безпеки держави. - Стаття.

Стаття присвячена дослідженню особливостей адміністративно-правового статусу Служби безпеки України як суб'єкта забезпечення фінансово-економічної безпеки держави. 3'ясовано сутність фінансово-економічної безпеки держави. Встановлено, що пріоритетним натепер є постійне відстеження та усунення факторів, які викликають загрози фінансово-економічній безпеці України, є напрямом діяльності держави та завданням правоохоронних органів. На підставі аналізу нормативно-правової бази визначено, що органи безпеки законодавець відносить до правоохоронних органів, а Служба безпеки України є правоохоронним органом спеціального призначення, який здійснює не лише правоохоронні, але й управлінські функції. Розглянуто підходи до розуміння змісту адміністративно-правового статусу Служби безпеки України. Наголошено на відсутності єдності науковців у визначенні структури адміністративно-правового статусу Служби безпеки України. Запропоновано до елементів адміністративно-правового статусу Служби безпеки України відносити мету, завдання, функції, організаційну структуру, компетенцію і юридичну відповідальність. Розкрито специфіку кожного із вищезазначених елементів. Встановлено, що законодавець не визначає функцій спецслужби у Законі Україні «Про Службу безпеки України». Зазначено, що в структурі Служби безпеки України діє Головне управління контррозвідувального захисту економічних інтересів держави, а здійснення контррозвідки є одним із пріоритетних повноважень Служби безпеки України. Виділено повноваження спецслужби зі здійснення інформаційно-аналітичної роботи, оперативно-розшукових заходів, досудового слідства, збереження державної таємниці, взаємодії з іншими суб'єктами, у тому числі правоохоронними органами. Акцентовано увагу на тому, що Служба безпеки України за рахунок державного бюджету відшкодовує шкоду, завдану незаконними діями, рішеннями та бездіяльністю їі співробітників, та може бути суб'єктом адміністративної відповідальності у разі оскарження рішень, дій чи бездіяльності її співробітників у порядку адміністративного судочинства.

Ключові слова: адміністративно-правовий статус, правоохоронні органи, Служба безпеки України, фінансово-економічна безпека держави.

\section{Summary}

Harust Yu. V., Stepanovsky V.S. The administrativelegal status of the Security Service of Ukraine as a subject of ensuring the financial and economic security of the state. - Article.

The article is devoted to the study of the peculiarities of the administrative and legal status of the Security Service of Ukraine as subject ensuring the financial and economic security of the state. The essence of financial and economic security of the state is revealed. Found that the continuous monitoring and eliminating factors that cause threat to financial and economic security of Ukraine is a 
priority area of state activity and tasks of law-enforcement agencies. Based on the analysis of the legal framework defines that the security authorities legislator refers to the law enforcement agencies and Security Service of Ukraine is the law enforcement agency for special purposes, which carries not only the law-enforcement, but administrative functions. Approaches to understanding the content of the administrative and legal status of the Security Service of Ukraine are considered. It was emphasized that there is no scientific unity in determining the structure of legal and administrative status of the Security Service of Ukraine. It is proposed to attribute to the elements of administrative and legal status of the Security Service of Ukraine the purpose, tasks, functions, organizational structure, competence and legal responsibility. The specifics of each of the above elements are disclosed. It was established that the legislator does not define the functions of the special service in the Law of Ukraine «On the Security Service of Ukraine». It is noted that in the structure of the Security Service of Ukraine there is the Main Directorate of counter-intelligence protection of the state economic interests and, accordingly, the conduct of counterintelligence is one of the priority powers of the Security Service of Ukraine. In addition, powers of the special service for the implementation of information-analytical work, operational and investigative measures, pre-trial investigation, preservation of state secrets, interaction with other entities, including law enforcement agencies are allocated. The attention is paid to the fact that the Security Service of Ukraine compensates for the damage caused by illegal actions, decisions and inactivity of its employees at the expense of the state budget and may also be the subject of administrative liability in case of appeal of decisions, actions or inactivity of its employees in the procedure of administrative legal proceedings.

Key words: administrative and legal status, law-enforcement agencies, Security Service of Ukraine, financial and economic security of the state. 